\title{
Groundwater recharge assessment in dry years
}

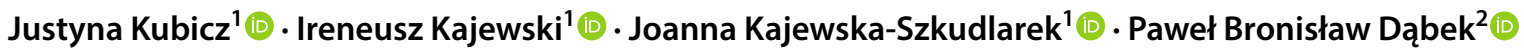

Received: 13 December 2018 / Accepted: 25 August 2019 / Published online: 3 September 2019

(c) The Author(s) 2019

\begin{abstract}
The climate change that has been observed in recent years has affected the water balance, including the groundwater resources recharge. The paper is an attempt to evaluate the groundwater recharge in dry years. The initial stage of the research consisted of selecting the years when meteorological and hydrological droughts occurred, with use of the standardized indices Standardized Precipitation Index (SPI) and Standardized Water Level Index (SWI). With the use of the WetSpass model for selected periods and for comparative long-term periods the volume of groundwater recharge was estimated. It was determined that the meteorological drought of 1982 led to a considerable decrease in the mean groundwater recharge to a negative level in the summer half-year in the Western Pomeranian region in Poland. On the other hand, the winter season was characterised by positive values, but they were still lower than those characteristic for the comparative long-term periods. The hydrological drought in 1992 did not have such noticeable consequences.
\end{abstract}

Keywords Water balance $\cdot$ WetSpass model $\cdot$ Western Pomerania $\cdot$ Poland $\cdot$ Groundwater recharge $\cdot$ Drought

\section{Introduction}

Groundwater is one of the natural resources that are the most important for human and for the environment. They provide potable water supply as well as water for industrial and agricultural use. They also ensure the environmental flow of rivers, lakes and wetland areas, contributing to the sustenance of biodiversity (Campbell and Konikow 2013). It is estimated that groundwater supply, globally, $50 \%$ of the required potable water and $40 \%$ of water used by the industry (Udmale et al. 2014).

Justyna Kubicz

justyna.kubicz@upwr.edu.pl

Ireneusz Kajewski

ireneusz.kajewski@upwr.edu.pl

Joanna Kajewska-Szkudlarek

joanna.kajewska-szkudlarek@upwr.edu.pl

Paweł Bronisław Dąbek

pawel.dabek@upwr.edu.pl

1 Institute of Environmental Engineering, Wroclaw University of Environmental and Life Sciences, 24 Grunwaldzki Sq., 50-363 Wrocław, Poland

2 Institute of Environmental Protection and Development, Wroclaw University of Environmental and Life Sciences, 24 Grunwaldzki Sq., 50-363 Wrocław, Poland
Groundwater recharge is an informative indicator of the water located beneath the ground surface. It has a direct impact on the volume of groundwater renewable supplies and, to a large extent, determines the degree of groundwater vulnerability to contamination. It is also of vital importance from the point of view of assessing the supplies, as well as protecting them against pollutants which penetrate an aquifer (Staśko et al. 2012).

The main factor influencing groundwater recharge is the atmospheric precipitation infiltration. This process depends on the geomorphological, geological, climatic, and biosphere-related factors, as well as on anthropogenic influences, i.e. human economic activity. These factors are characterised by high spatial variability. In temporal terms, some of them may be considered relatively stable, while others (mainly climatic and meteorological ones) are subject to constant changes, both in the long-term period and within a single year or even in shorter periods (Kowalski 2007; Tarka and Staśko 2001; Staśko and Chodacki 2014).

The presented research used the WetSpass model developed by Batelaan (2006), Batelaan and De Smedt (2001) to evaluate groundwater recharge for the Western Pomeranian region in Poland. It was initially designed to perform modeling within the borders of a catchment. It also proved useful for the evaluation of water balance in areas that are not catchments: in the Gaza Strip (Aish et al. 2010; Aish 
2014), Poznan Plateau (Graf and Przybyłek 2014), the Delta of the Nile (Armanuos et al. 2016) and Western Pomerania (Kajewska-Szkudlarek et al. 2017). Numerous authors have used the WetSpass model to evaluate the influence of climate and land-use changes on specific elements of the water balance. Woldeamlak et al. (2007) modeled the modifications in the volume of groundwater resources in the Grote-Nete catchment in Belgium, in the light of climate changes, with use of three scenarios: cool, wet and dry. Wang et al. (2015) analysed the alterations in water balance components as a consequence of the basic climate elements changes for two main scenarios according to the IPCC (A2 and B2) in the area of the upper part of the Yangtze River of a surface area of 983 thousand $\mathrm{km}^{2}$. The publications by Aish et al. (2010), Mogheir and Ajjur (2013) and Gharbia et al. (2015a, b) discussed the influence of climate change on the groundwater resources in the Gaza Strip. The objective of the study Graf and Przybyłek (2018) was to identify factors conditioning recharge of shallow groundwater in selected catchment areas of the Poznań Upland using the WetSpass simulation water balance model with spatially distributed parameters. Another research aimed to use WetSpass model to estimate long-term average annual and seasonal groundwater recharge for Birki watershed $\left(45 \mathrm{~km}^{2}\right)$ in northern Ethiopia using long-term (10 years) hydro-meteorological and biophysical (soil, land use, topography, slope and groundwater depth) data of the watershed (Meresa and Taye 2018).

The objective of the study was the evaluation of the groundwater recharge in dry years. Modeling results will provide initial information on the changes in groundwater recharge volume in years with droughts. The obtained knowledge may be useful in water management during droughts and afterwards and in studies on the contamination groundwater vulnerability.

\section{Study area}

Simulations covered the area of Western Pomerania, of a total area of 18.82 thousand $\mathrm{km}^{2}$, bounded to the Baltic Sea to the north. It stretches between parallels from $52^{\circ} 37^{\prime}$ to $54^{\circ} 33^{\prime}$ and meridians from $14^{\circ} 07^{\prime}$ to $16^{\circ} 58^{\prime}$. Western Pomerania consists of the physicogeographical province of Central European Plain and two sub-provinces distinguished due to their geomorphological and mezoclimatic differentiation: The Southern Baltic Coasts and the Southern Baltic Lakes. Their distinctive characteristics include, first of all, specific land formation properties and the structure of superficial geological layers. The northern part is a belt of coastal lowlands, while the southern part of the area is the lake district zone. One of the characteristic properties of Western Pomerania is the abundance of surface water, which, together with seawater, account for a total share of
$5.2 \%$ of its area (Czarnecka 2005). The land usage structure is dominated by arable land (approx. 49\%) and wooded areas (36\%) [Rocznik Statystyczny Województwa Zachodniopomorskiego (The Statistical Yearbook of the Western Pomeranian Voivodeship)-2017]. The physiographic conditions and the vicinity of the Baltic Sea and the Szczecin Lagoon result in significant differences between individual meteorological factors. Based on the analyses of meteorological data, Koźmiński et al. (2007) defined ten climatic regions characterised by different weather conditions. This classification results from a high variety and changeability of the climate, which is caused by the clash between the maritime climate (in the northern and western parts) with the continental climate (in regions further away from the seaside and to the east) and the influence of local factors. The characteristic properties are high air humidity, a dominance of western and north-western winds as well as increased precipitation in the most elevated areas. The average total annual precipitation is $650-800 \mathrm{~mm}$. The climate on the Baltic coast may be described as moderate warm maritime climate, while in the inland areas as moderate warm transitional climate.

The main groundwater resources in this area are present in quaternary formations, which, in young glacial conditions, are sands, gravels and clays. Water that is present in older formations (from the Jurassic and Cretaceous periods) is of low, local importance only. Aquifers that have the most advantageous location in terms of their accessibility and good insulation from the land cover are situated in the valleys of the Odra and Ina Rivers. The distribution of groundwater is very uneven. The richest resources exist in the central and southern parts of the analysed area, in places where they are not exploited due to low population and the absence of larger settlements. The densely populated coastal area and the regions in the vicinity of large towns struggle with deficits of water resources, especially those of good quality. In general, the quality of groundwater in the region is deteriorating as a result of the contact with saline and seawater in the northern part of Western Pomerania (Bacik et al. 2012; Racinowska-Ratajska et al. 2018).

\section{Materials and methods}

\section{Standardized precipitation index}

The index method was used to determine the specific years, in which drought had a significant influence on the elements of water balance. SPI which is commonly quoted and applied in literature (Bąk and Łabędzki 2014; Bordi et al. 2009; Kumar et al. 2016; Łabędzki and Bąk 2002; Barker et al. 2016), was used as meteorological drought indicator. 
In spite of reservations made by certain authors, who pointed to the potential limitations of the application of this indicator (Bloomfield and Marchant 2013) it is recommended by the World Meteorological Organization (WMO) for operational monitoring of drought risk (2012). The Standardized Water Level Index (SWI) calculated based on water levels (Bąk and Kubiak-Wójcicka 2016; Bhuiyan et al. 2006) was the hydrological indicator used for the purposes of this study. The values of the indices used are standardised deviations of precipitation and water level from the median value in the analysed long-term period. Good adjustment to the normal distribution of homogeneous sequence of rainfall was obtained with use of the function $\sqrt[3]{X}$ (Eabędzki and Bakk 2002.). For water levels, the 2-parametric logarithmic function (Ozga-Zielińska and Brzeziński 1994; VicenteSerrano et al. 2012) was used as recommended in subject literature. The compliance of the distribution of transformed variable with normal distribution was analysed with use of the $X^{2}$ consistency test (Pearson's or Kolmogorov-Smirnov test). Positive value of the consistency test allowed us to calculate the value of indices with use of the equation:

$X=\frac{f(X)-\mu}{\delta}$,

where $X$ represents the chosen index (SPI, SWI), $f(X)$ represents the transformer sums of precipitation, water levels, $\mu$ represents the mean of normalized index $X, \delta$ represents the standard deviation of index $X$.

A common, 4-class evaluation of drought intensity was adopted for the indicators whose values met the $X<0$ criterion, according to the guidelines provided by Łabędzki and Bąk for Poland (2002).

\section{Data collection}

A geostatistical estimation of the value of these elements was performed for the input data on air temperature, wind speed, evaporation from water surface and the amount of precipitation obtained from measurement sites in Western Pomerania. Spatial interpolation in the ArcGIS environment. As a result, raster maps of climatic parameters were obtained, in $100 \mathrm{~m}$ GRID format according to the resolution of a Digital Terrain Model (DTM).

The data used for simulations in the model test area were made available by IMGW-PIB (Institute of Meteorology and Water Management-National Research Institute). Information about land cover in vector form-Corine Land Cover (CLC) 2012 from the databases of the Main Inspectorate for Environmental Protection was also used for modelling in the WetSpass software. The Voivodeship Geodesic and Cartographic Documentation Center (WODGiK) provided vector soil and agricultural maps in the 1:25,000 scale. The map of the depth of groundwater was developed basing on the informational layer of the hydrographic map in the scale of 1: 50,000 containing hydro isobaths. A set of elevation points arranged in a normal grid of a $100 \mathrm{~m}$ mesh size was obtained from the database of the Head Office of Land Surveying and Cartography (Table 1 ).

These data constituted the basis for the creation of a DTM with a resolution of $100 \mathrm{~m}$ and the map of terrain slope of the same spatial resolution. All maps were made in coordinate system PL-92 (Table 1).

\section{WetSpass simulation model}

Simulation tests were conducted with the use of the WetSpass model to obtain maps of the spatial distribution of the main water balance components: actual evapotranspiration, surface runoff and groundwater recharge. The analyses were conducted for two 30-year periods: 1971-2000, 1981-2010 and the years: 1982, when meteorological drought was noted, and 1992, when surface water drought was noted. In climate sciences, the period 1971-2000 is considered climatological norm (Lorenc 2005), while
Table 1 Input data and its sources

\begin{tabular}{llll}
\hline ID & Parameter & Source & Resolution \\
\hline 1 & Seasonal temperature & IMGW-PIB & $100 \times 100 \mathrm{~m}$ \\
2 & Seasonal precipitation & IMGW-PIB & $100 \times 100 \mathrm{~m}$ \\
3 & Seasonal wind speed & IMGW-PIB & $100 \times 100 \mathrm{~m}$ \\
4 & Seasonal potential evapotranspiration & IMGW-PIB & $100 \times 100 \mathrm{~m}$ \\
5 & Seasonal land cover & Corine Land Cover (CLC) 2012 & $100 \times 100 \mathrm{~m}$ \\
6 & Soil & WODGiK & $100 \times 100 \mathrm{~m}$ \\
7 & Seasonal groundwater depth & WODGiK & $100 \times 100 \mathrm{~m}$ \\
8 & DTM & Head Office of Land Surveying and & $100 \times 100 \mathrm{~m}$ \\
& & Cartography & \\
9 & Soil parameter lookup table & WetSpass model & \\
10 & Runoff coefficient lookup table & WetSpass model & \\
11 & Land use parameters lookup table & WetSpass model & \\
\hline
\end{tabular}


the years when temperature records and increased precipitation were noted in Poland occurred in the period 2000-2010, which is covered by the 1981-2010 long-term period (Kajewska-Szkudlarek et al. 2017). It was assumed that these two periods provide the proper background for the analysis of the potential changeability of groundwater recharge in dry years.

The applied WetSpass (Water and Energy Transfer between Soil, Plants and Atmosphere under quasi-Steady State) simulation model is an extension to the ArcView GIS software. It is based on spatial data analysis in raster format. It uses a series of equations of the evaporation process physics and empirical correlations (Batelaan and De Smedt 2001; Batelaan 2006). Input data for simulation calculations consist of 8 numerical (raster) maps that present: land use, types of soils (according to grain size distribution), the depth of groundwater level, total precipitation (P), indicative (open water) evaporation, wind speed, air temperature and terrain slope. On the base of spatial data surface runoff (SR), plant transpiration $(\mathrm{Tr})$ as well as canopy interception (In) are calculated for each raster cell, then groundwater recharge (GR) is calculated according to the following balance equation:

$\mathrm{GR}=\mathrm{P}-\mathrm{SR}-\mathrm{Tr}-\mathrm{In}$.

All components of water balance are assessed on the soil surface and further water movement in vadose zone is not considered though. For the long-term quasi Steady State conditions geological parameters as anisotropy, permeability as well as bedding effects, which affect groundwater recharge (Aryafar and Ardejani 2009) are neglected.

As a result of the simulations, numerical results are obtained and raster maps of the spatial distribution of specific water balance components for the analysed area, divided into the summer and winter half-years and for the whole year are prepared (Armanous and Negm 2016; Graf 2014; Melki et al. 2017).

\section{Results and discussion}

Representative 2 years: 1982 and 1992 were selected for the evaluation of the groundwater recharge during drought periods. This selection was dictated by the results of Standardized Precipitation Index and Standardized Water Level Index analyses on a 1 year scale in the analysed area. Additionally, a detailed analysis of monthly time series of SPI values was performed for two selected measurement points in Resko and in Szczecin. In 1982, in Resko, 2 periods of meteorological drought were noted (February-April and June-December). In both cases, months with extreme drought (SPI $>-2$ ) were noted. On the Szczecin station, meteorological drought occurred from February to September 1982. Here, also, the drought of extreme intensity was found (Table 2).The analysis based on SWI in two selected points, on the Rega River in Resko and on the Ina River in Stargard Szczeciński, demonstrated that all months should be considered as dry. Additionally, in the Resko station, extreme drought was noted in June and July. In Stargard Szczeciński the lowest SWI value was calculated for July and it confirmed the existence of strong drought (Table 3).

The groundwater recharge was evaluated with the use of the water balance method. The balance takes into account the water supply in form of precipitation and water loss resulting from groundwater recharge, surface runoff or actual evapotranspiration. Two basic types of groundwater recharge were found in the analysed area: precipitation and surface water infiltration. It was found that the groundwater is recharged mainly by rainwater. This factor was taken into consideration in further analyses.

Mean annual precipitation (P) in Western Pomerania for the analysed long-term periods was $580 \mathrm{~mm}$ (1971-2000) and $628 \mathrm{~mm}$ (1981-2010), with the extreme values ranging from 184 to $817 \mathrm{~mm}(1971-2000)$ and $364-839 \mathrm{~mm}$ (1981-2010). In dry years, these values were, respectively,

Table 2 Values of SPI in study sites in 1982

\begin{tabular}{|c|c|c|c|c|c|c|c|c|c|c|c|c|}
\hline \multirow[t]{2}{*}{ Site } & \multicolumn{12}{|c|}{ Month } \\
\hline & Jan & Feb & Mar & Apr & May & Jun & Jul & Aug & Sep & Oct & Nov & Dec \\
\hline Resko & 0.37 & -2.04 & -1.01 & -0.11 & 0.34 & -0.39 & -1.02 & -2.02 & -3.06 & -0.40 & -0.77 & -0.08 \\
\hline Szczecin & 0.59 & -1.63 & -0.23 & -1.22 & -0.02 & -0.07 & -1.34 & -1.89 & -2.32 & 0.11 & -0.67 & -0.60 \\
\hline
\end{tabular}

Table 3 Values of SWI in study sites in 1992

\begin{tabular}{|c|c|c|c|c|c|c|c|c|c|c|c|c|}
\hline \multirow[t]{2}{*}{ Site } & \multicolumn{12}{|l|}{ Month } \\
\hline & Jan & Feb & Mar & Apr & May & Jun & Jul & Aug & Sep & Oct & Nov & Dec \\
\hline Resko & -1.34 & -1.26 & -0.70 & -0.81 & -1.09 & -2.22 & -2.28 & -1.61 & -1.28 & -1.51 & -1.00 & -1.31 \\
\hline Stargard Szcz. & -0.41 & -0.49 & -0.35 & -0.28 & -0.10 & -1.49 & -1.74 & -1.46 & -1.06 & -1.62 & -1.03 & -1.38 \\
\hline
\end{tabular}


$400 \mathrm{~mm}$ in 1982 and $531 \mathrm{~mm}$ in 1992. The minimum and maximum values were, respectively, 292 and $610 \mathrm{~mm}$ in 1982 and 389 and 739 in 1992. Precipitation in the summer half-year accounted for $56 \%$ of the average total annual precipitation for both long-term periods. In 1982 it accounted for $51 \%$, while in 1992 - for $44 \%$ of the average total annual precipitation.

Figure 1 shows the results of the spatial simulation of the volume of groundwater recharge for the long-term periods 1971-2000, 1981-2010 and the dry years 1982 and 1992. In 1982 no areas were found where the recharge would exceed $250 \mathrm{~mm}$ year $^{-1}$, while in 1992 it was $300 \mathrm{~mm}$ year $^{-1}$. In 1992 almost $30 \%$ of the area was characterised by a relatively low groundwater recharge that ranged from 50 to $100 \mathrm{~mm}$ year $^{-1}$. In the year 1992 and in the compared long-term period 1971-2000 the largest area, accounting for $37 \%$ of the total area, was characterised by recharge of 100-150 $\mathrm{mm}$ year $^{-1}$. In the period 1981-2010 areas with

(a)

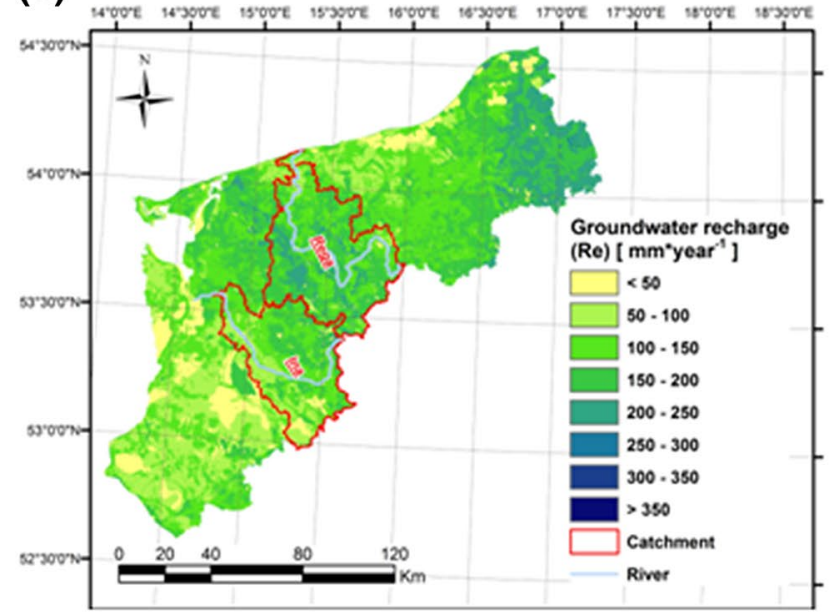

(c)

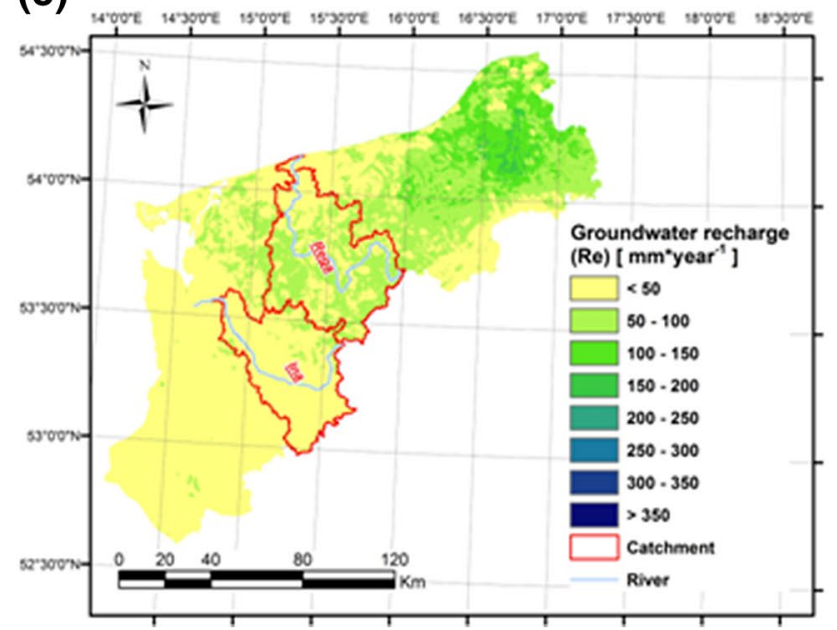

a recharge of $150-200 \mathrm{~mm}$ year $^{-1}$ had the highest share (24\%). Areas with the highest groundwater recharge, above $350 \mathrm{~mm} \mathrm{year}^{-1}$ were also found in this long-term period.

The mean annual groundwater recharge in the long-term period 1971-2000 was $130 \mathrm{~mm}$ year $^{-1}$, and in 1981-2010 it was $158 \mathrm{~mm}_{\text {year }}{ }^{-1}$. In the years 1982 and 1992 mean groundwater recharge was 40 and $115 \mathrm{~mm} \mathrm{year}^{-1}$. Values obtained from simulations for specific periods are presented in Fig. 2. In the summer season, the values of groundwater recharge were negative. This proves the dominance of the evapotranspiration process and the low significance of the influence of summer rainfall on the changes in groundwater levels (or the lack of such influence). The year 1982, described as dry was the only one characterised by negative mean annual groundwater recharge value in the summer half-year. Negative values of groundwater recharge were noted particularly in valley lowering areas that perform drainage functions. This results from considerable plant

(b)

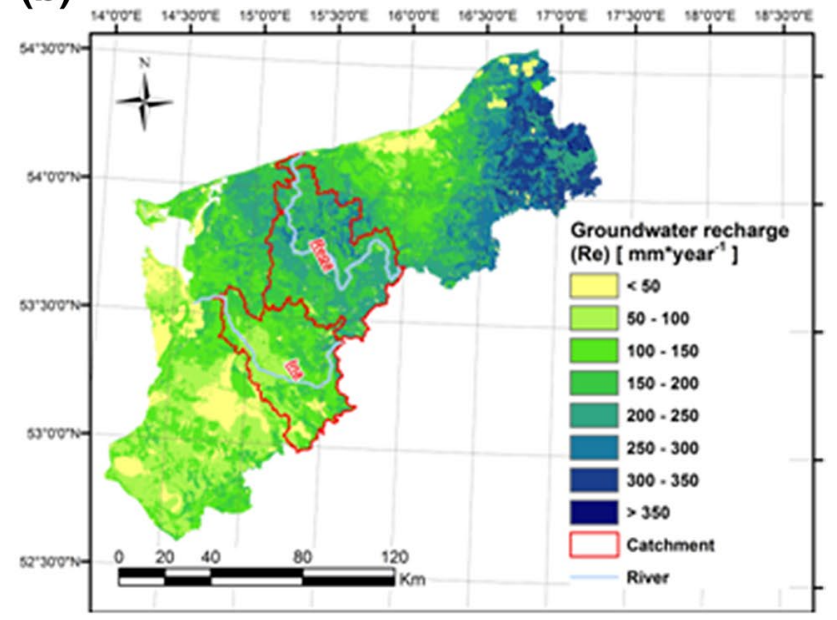

(d)

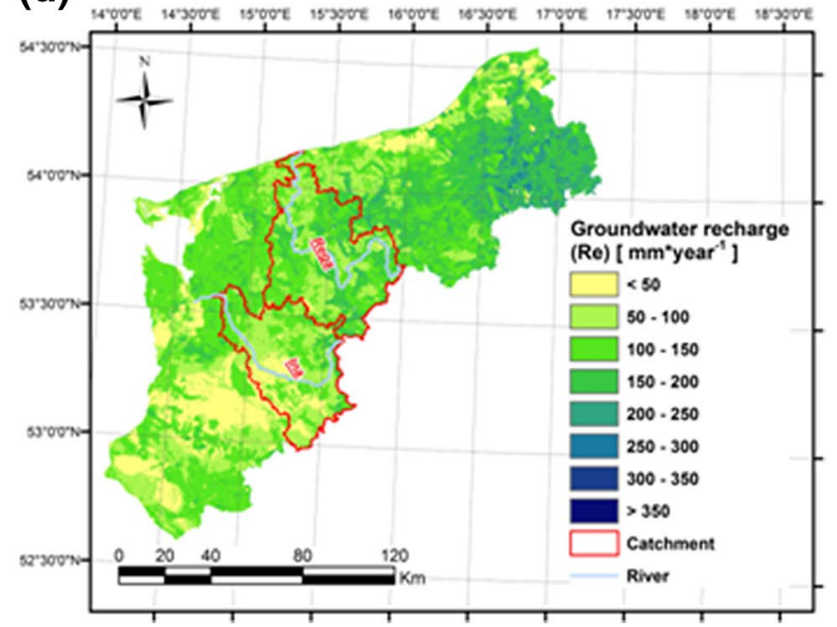

Fig. 1 Spatial distribution of annual groundwater recharge for Western Pomerania in periods: a 1971-2000, b 1981-2000 (long-term mean), c in 1982 and d 1992 (annual mean values) 


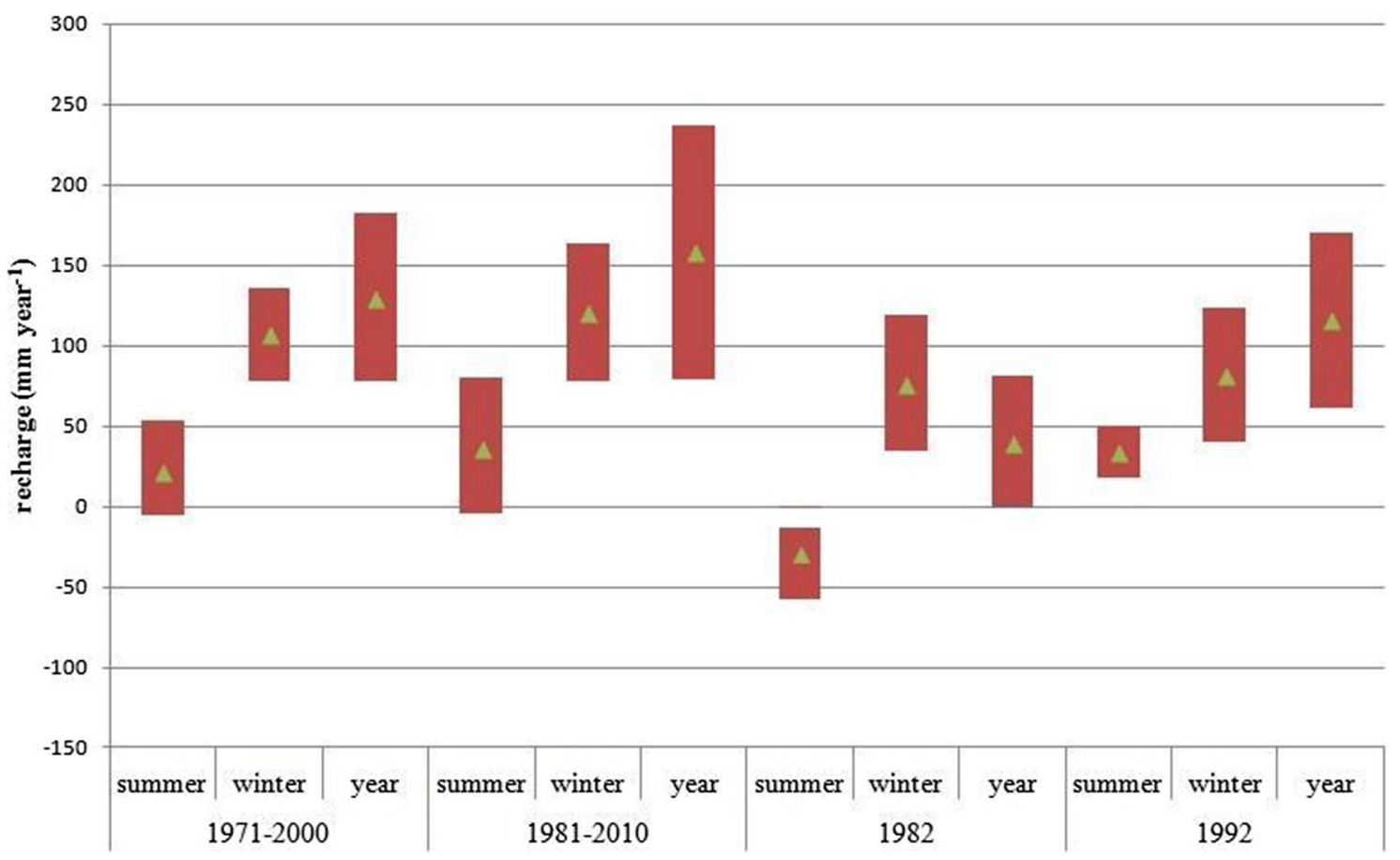

Fig. 2 Range of the variability of annual groundwater recharge for Western Pomerania

transpiration in areas with shallow groundwater. The same observations were made by Batelaan (2006).

Considering mean annual values, a dominance of actual evapotranspiration over groundwater recharge and surface runoff was found (Fig. 3), provided that actual evapotranspiration is defined as the sum of evaporation from the soil, plant transpiration and the interception of rainwater. The highest percentage share of evapotranspiration in the water balance (88\%) was noted in 1982. In that year, groundwater recharge accounted for only $9 \%$ share in the water balance. In the winter half-year, the relations between water balance components changed to the benefit of groundwater recharge in all cases. The value of actual evapotranspiration was, on average, $30 \%$ lower in comparison to the situation throughout the year. The surface runoff value decreased as well. In the summer half-year a reduction in the groundwater recharge value was noted (Table 3 ). Surface runoff was the water balance component that accounted for the
Fig. 3 Selected water balance components in Western Pomerania
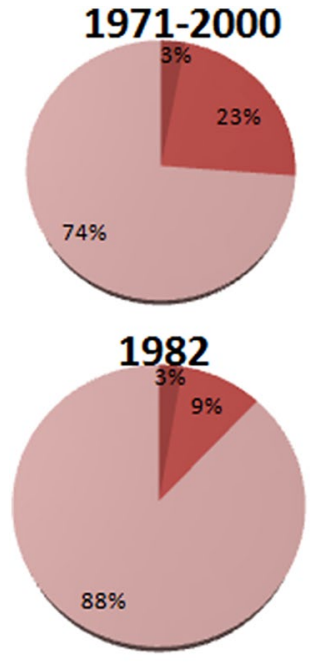

$\square$ Surface runoff $\square$ Groundwater recharge $\square$ Actual evapotranspiration 
lowest percentage share in the annual scale and in both half-year periods in all temporal simulations. The average value of surface runoff ranged from $12 \mathrm{~mm} \mathrm{year}^{-1}$ in 1982 to $19 \mathrm{~mm} \mathrm{year}^{-1}$ in the 1981-2010 period. On average, it accounted for approx. $3 \%$ of the water balance components in of Western Pomerania (Fig. 3). In the long-term periods, in the warm half-years, the surface runoff was, on average, $60 \%$ higher than in winter seasons. In dry years this difference was smaller and reached 42\% in 1982 and 44\% in 1992. The mean values of the selected water balance components divided into the summer and winter half-year are presented in Table 4.

\section{Validation of groundwater recharge assessment results}

To verify the presented simulation results conducted with the use of the WetSpass model, their reliability was assessed by comparing the results of the estimated groundwater recharge in the Western Pomeranian Region with the results of groundwater outflow calculated with the use of hydrological methods (Herbich et al. 2014). The comparisons were conducted for two hydrological catchments: of the Rega River (to the cross-section of the stream gauge in Resko, of a surface area of $1133.58 \mathrm{~km}^{2}$ ) and the Ina River to the stream gauge cross-section in Stargard Szczeciński, of a surface area of $1773.83 \mathrm{~km}^{2}$, boundaries of above-mentioned catchments are shown in the Fig. 1. Groundwater outflow at the aforementioned stream gauge cross-sections was calculated with use of three hydrological methods: the genetic outflow division method (GODM), the Wundt's and Kille's methods. Data for hydrological methods comprises period 1971-2000.

The values of groundwater outflow calculated with use of hydrological methods and the average value of groundwater recharge for these catchments estimated with use of the WetSpass model are presented in Table 5.

The results of the conducted verification demonstrate that the differences between groundwater outflows calculated with the use of various hydrological methods are rather large: $26.2 \mathrm{~mm}$ year $^{-1}(18.7 \%)$ in Rega River catchment and $27.2 \mathrm{~mm}$ year $^{-1}(22.6 \%)$ in the case of Ina River catchment. On the other hand, the average annual value of groundwater recharge estimated based on simulations conducted with the
Table 5 Comparison of groundwater outflow calculated by hydrological methods with groundwater recharge assessed by means of WetSpass model

\begin{tabular}{|c|c|c|c|c|}
\hline \multirow[t]{2}{*}{ Catchment } & \multicolumn{3}{|c|}{ GW outflow by the method: } & \multirow{2}{*}{$\begin{array}{l}\text { WetSpass } \\
\text { groundwater } \\
\text { recharge } \\
\left(\mathrm{mm}^{2} \text { year }^{-1}\right)\end{array}$} \\
\hline & $\begin{array}{l}\text { GODM } \\
\left(\mathrm{mm} \mathrm{year}^{-1}\right)\end{array}$ & $\begin{array}{l}\text { Wundt } \\
\left(\mathrm{mm}_{\text {year }}{ }^{-1}\right)\end{array}$ & $\begin{array}{l}\text { Kille } \\
\left(\mathrm{mm} \mathrm{year}^{-1}\right)\end{array}$ & \\
\hline Rega & 219.8 & 199.5 & 193.6 & 174.91 \\
\hline Ina & 147.4 & 125.9 & 120.2 & 125.93 \\
\hline
\end{tabular}

use of the WetSpass model is only slightly different from the groundwater outflow calculated with use of hydrological methods. Especially small differences in this respect have been noted for the Ina River catchment, where the difference between groundwater outflow according to the Kille's method and groundwater recharge based on the WetSpass model is only $-5.7 \mathrm{~mm} \mathrm{year}^{-1}$ (less than $5 \%$ ), in the case of Rega River catchment the difference between Kille's method and WetSpass result was $18.7 \mathrm{~mm}_{\text {year }}{ }^{-1}(10.7 \%)$.

\section{Conclusions}

The simulations conducted to evaluate the water balance of Western Pomerania with the use of WetSpass model enabled to estimate the groundwater recharge in periods considered as dry. According to standardised drought indicators, a meteorological drought (shown by the SPI indicator) took place in 1982, while in 1992 a hydrological drought occurred (as confirmed by the SWI indicator).

The conducted research allowed the authors to conclude that the drought noted in 1982 was outstanding in terms of water balance structure. It caused an increase in the share of evapotranspiration in the water balance of the analysed area (to 88\%), which in turn led to diminished groundwater recharge (only 9\%). On the other hand, the consequences of the drought of 1992 for the distribution of water balance components were much less significant (evapotranspiration $77 \%$, groundwater recharge $21 \%$ ).

In 1982, a significant decrease was noted in the average groundwater recharge in the summer half-year, to a negative level $\left(-37 \mathrm{~mm}\right.$ year $\left.{ }^{-1}\right)$. Although the winter season
Table 4 Values of the selected water balance components in the summer and winter halfyear in Western Pomerania

\begin{tabular}{llcrrr}
\hline Period & Water balance component & $1971-2000$ & $1981-2000$ & 1982 & 1992 \\
\hline \multirow{2}{*}{ Summer } & Surface runoff $\left(\mathrm{mm} \mathrm{year}^{-1}\right)$ & 11 & 12 & 7 & 9 \\
& Groundwater recharge $\left(\mathrm{mm} \mathrm{year}^{-1}\right)$ & 22 & 36 & -37 & 34 \\
& Actual evapotranspiration $\left(\mathrm{mm} \mathrm{year}^{-1}\right)$ & 281 & 297 & 242 & 207 \\
\multirow{3}{*}{ Winter } & Surface runoff $\left(\mathrm{mm} \mathrm{year}^{-1}\right)$ & 6 & 7 & 4 & 5 \\
& Groundwater recharge $\left(\mathrm{mm} \mathrm{year}^{-1}\right)$ & 107 & 121 & 76 & 82 \\
& Actual evapotranspiration $\left(\mathrm{mm} \mathrm{year}^{-1}\right)$ & 133 & 142 & 134 & 221 \\
\hline
\end{tabular}


was characterised by positive values $\left(76 \mathrm{~mm} \mathrm{year}^{-1}\right)$, they remained lower than those characteristic for the compared long-term periods 1971-2000 and 1981-2010 (respectively, 107 and $121 \mathrm{~mm}$ year $^{-1}$ ). The hydrological drought (1992) did not cause such visible results in the summer season (1992), but the winter season was characterised by groundwater recharge similar to that noted during meteorological drought and lower than in the 30 -year period $\left(82 \mathrm{~mm} \mathrm{year}^{-1}\right)$.

However, when evaluating the results obtained from the Wetspass model, one should bear in mind that, as any other model, it provides only a simplified reflection of reality. Still, it allows assessing the trends of the influence of climate changes on groundwater recharge, which is impossible to achieve with the use of other methods.

Acknowledgements The research was carried out with the statutory activity funds of the Faculty of Environmental Engineering and Geodesy, Wroclaw University of Environmental and Life Sciences in 2017, with agreement number B030/0102/17.

Open Access This article is distributed under the terms of the Creative Commons Attribution 4.0 International License (http://creativeco mmons.org/licenses/by/4.0/), which permits unrestricted use, distribution, and reproduction in any medium, provided you give appropriate credit to the original author(s) and the source, provide a link to the Creative Commons license, and indicate if changes were made.

\section{References}

Aish AM (2014) Estimation of water balance components in the Gaza Strip with GIS based WetSpass model. Civil Environ Res 6:11

Aish MA, Batelaan O, De Smedt F (2010) Distributed recharge estimation for groundwater modeling using WetSpass model, case study—Gaza strip, Palestine. Arab J Sci Eng 35(1):155

Armanous AM, Negm A (2016) Assessment of the variations of local parameters of Wetspass model: case study Nile Delta aquifer. Proc Eng 154:276-283

Armanuos AM, Negm A, Yoshimura C (2016) Aplication of WetSpass model to estimate groundwater recharge variability in the Nile Delta aquifer. Arab J Geosci 9(10):553

Aryafar A, Ardejani FD (2009) Anisotropy and bedding effects on the hydro geological regime in a confined aquifer to design an appropriate dewatering system. Int J Environ Sci Technol 6(4):563-570

Bacik A, Dobies M, Jezierski P, Wiśniowski Z, Hoc R, Fuszara P (2012) Identyfikacja oddziaływań zmian poziomów wód podziemnych w obszarze RZGW Szczecin z uwzględnieniem zmian klimatu. Państwowy Instytut Geologiczny (in Polish)

Bąk B, Kubiak-Wójcicka K (2016) Assessment of meteorological and hydrological drought in Torun (central Poland town) in 1971-2010 based on standardized indicators. In: 3rd International Conference: water resources and wetlands, Tulcea, Romania, pp. 164-170

Bąk B, Łabędzki L (2014) Prediction of precipitation deficit and excess in Bydgoszcz Region in view of predicted climate change. J Water Land Dev 23(X-XII):11

Barker LJ, Hannaford Chiverton A, Svensson C (2016) From meteorological to hydrological drought using standardised indicators. Hydrol Earth Syst Sci 20:2483-2505
Batelaan O (2006) Phreatology: characterizing groundwater recharge and discharge using remote sensing, GIS, ecology, hydrochemistry and groundwater modelling. Vrije Universiteit, Brussel

Batelaan O, De Smedt F (2001) WetSpass: a flexible, GIS based, distributed recharge methodology for regional groundwater modelling. IAHS Publication, Wallingford, pp 11-18

Bhuiyan C, Singh RP, Kogan FN (2006) Monitoring drought dynamics in the Aravalli region (India) using different indices based on ground and remote sensing data. Int J Appl Earth Observ Geoinform 8(4):289

Bloomfield JP, Marchant BP (2013) Analysis of groundwater drought building on the standardized precipitation index approach. Hydrol Earth Syst Sci 17:4769

Bordi I, Fraedrich K, Sutera A (2009) Observed drought and wetness trends in Europe: an update. Hydrol Earth Syst Sci 13:1519

Campbell J, Konikow L (2013) Deficit in Nation's Aquifers Accelerating. US Geological Survey, Press Release

Czarnecka H (ed) (2005) Atlas podziału hydrograficznego Polski: praca zbiorowa. Zestawienia zlewni. Instytut Meteorologii i Gospodarki Wodnej

Gharbia SS, Aish A, Pilla F (2015a) Francesco. Impacts of climate change on a spatially distributed water balance in the Gaza Strip, Palestine. J Environ Earth Sci 5:76-91

Gharbia SS, Aish A, Pilla F (2015b) Modelling potential impacts of climate change on groundwater of the Gaza coastal aquifer from ensemble of global climate model projections. Civ Environ Res $7: 44-60$

Graf R (2014) Zastosowanie modelu WetSpass zintegrowanego z GIS w estymacji obszarowej składowych bilansu wodnego zlewni. Problemy badań wody w XX i XXI wieku, p. 144-159 (in Polish)

Graf R, Przybyłek J (2014) Estimation of shallow groundwater recharge using a GIS-based distributed water balance model. Quaestiones Geographicae 33(3):27-37

Graf R, Przybyłek J (2018) Application of the WetSpass simulation model for determining conditions governing the recharge of shallow groundwater in the Poznań Upland, Poland. Geologos 24(3):189-205

Herbich P, Kapuściński J, Nowicki K, Rodzoch A (2014) Metodyka określania zasobów dyspozycyjnych wód podziemnych w obszarach bilansowych z uwzględnieniem potrzeb jednolitych bilansów wodnogospodarczych - poradnik metodyczny. Narodowy Fundusz Ochrony Środowiska i Gospodarki Wodnej, Ministerstwo Środowiska, Warszawa (in Polish)

Kajewska-Szkudlarek J, Kubicz J, Kajewski I, Dąbek PB (2017) Ocena zasobów odnawialnych wód podziemnych Pomorza Zachodniego na podstawie modelu symulacyjnego WetSpass. Przegląd Geologiczny $65: 11 / 1$

Kowalski J (2007) Hydrogeologia z podstawami geologii. Wydawnictwo Uniwersytetu Przyrodniczego (in Polish)

Koźmiński C, Michalska B, Czarnecka M, Podlasiński M (2007) Klimat województwa zachodniopomorskiego. PPH ZAPOL Dmochowski, Sobczyk

Kumar R, Musuuza JL, Van Loon AF, Teuling AJ, Barthel R, Ten Broek J, Mai J, Samaniego L, Attinger S (2016) Multiscale evaluation of the standardized precipitation index as a groundwater drought indicator. Hydrol Earth Syst Sci 20:1117-1131

Łabędzki L, Bąk B (2002) Monitoring of droughts using the standardized precipitation index SPI. Woda-Środowisko-Obszary Wiejskie 2(5):9

Lorenc H (2005) Atlas klimatu Polski. IMGW, Warszawa (in Polish)

Melki A, Abdollahi K, Fatahi R, Abida H (2017) Groundwater recharge estimation under semi arid climate: case of Northern Gafsa watershed, Tunisia. J Afr Earth Sci 132:37-46

Meresa E, Taye G (2018) Estimation of groundwater recharge using GIS-based WetSpass model for Birki watershed, the eastern zone 
of Tigray, Northern Ethiopia. Sustain Water Resour Manag. https ://doi.org/10.1007/s40899-018-0282-0

Mogheir Y, Ajjur S (2013) Effects of climate change on groundwater resources (Gaza strip case study). Int J Sustain Energy Environ $1: 136-149$

Ozga-Zielińska M, Brzeziński J (1994) Hydrologia stosowana. Wyd. Naukowe PWN (in Polish)

Racinowska-Ratajska M, Skrzeszowska-Jaksina I, Woziński R, Zieliński T (2018) Opracowanie ekofizjograficzne do planu zagospodarowania przestrzennego województwa zachodniopomorskiego. Regionalne Biuro Gospodarki Przestrzennej województwa zachodniopomorskiego, Szczecin (in Polish)

Rocznik Statystyczny Województwa Zachodniopomorskiego-2017 (2017) GUS, Warszawa

Standardized Precipitation Index User Guide (2012) WMO, 1090

Staśko S, Chodacki M (2014) Infiltracja do wód podziemnych na podstawie pomiarów lizymetrycznych w Górach Sowich. Przegląd Geologiczny 62(8):414-419 (In Polish)

Staśko S, Tarka R, Olichwer T (2012) Groundwater recharge evaluation based on the infiltration method. Select Papers Hydrogeol 17:189-197

Tarka R, Staśko S (2001) Zasilanie wód podziemnych na obszarze masywu Śnieżnika. Współczesne problemy hydrogeologii (in Polish)
Udmale P, Shrestha S, Ichikawa Y, Manandhar S (2014) Assessing groundwater resource and its sustainability in drought prone area of India. J Jpn Soc Civ Eng Ser B2 (Coastal Engineering) 70(4):I_235-I_240

Vicente-Serrano SM, Begueria V, Lorenzo-Lacruz J, Camarero JJ, López-Moreno JI, Azorin-Molina C, Revuelto J, Moran-Tejeda E, Sanchez-Lorenzo A (2012) Performance of drought indices for ecological, agricultural, and hydrological applications. Earth Interact 16(10): 1-27

Wang Y, Liao W, Ding Y, Wang X, Jiang Y, Song X (2015) Water resource spatiotemporal pattern evaluation of the upstream Yangtze River corresponding to climate changes. Quat Int 380:187-196

Woldeamlak ST, Batelaan O, De Smedt F (2007) Effects of climate change on the groundwater system in the Grote-Nete catchment, Belgium. Hydrogeol J 15(5):891-901

Publisher's Note Springer Nature remains neutral with regard to jurisdictional claims in published maps and institutional affiliations. 